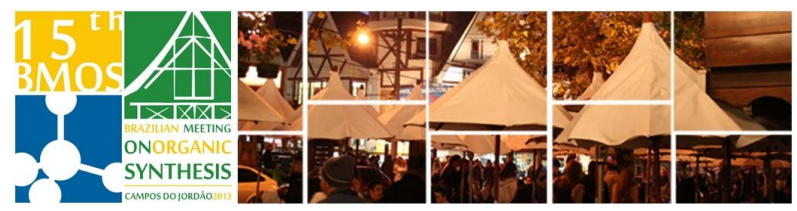

\title{
Cross-coupling reactions as a strategy for Naphthalocyanine synthesis
}

\author{
Nicholas R. S. Gobo, Timothy J. Brocksom and Kleber T. de Oliveira* \\ Universidade Federal de São Carlos - UFSCar, Departamento de Química,13565-905, São Carlos, SP,
} Brazil.

*e-mail: kleber.oliveira@ufscar.br, www.lqbo.ufscar.br

Keywords: phthalocyanines, cross-coupling, naphthalocyanines, materials science

\section{INTRODUCTION}

Naphthalocyanines are a third order class of photosensitizers with a highly $\pi$-conjugated system, allowing absorption in near-infrared spectra. ${ }^{1}$ Photosensitizers with absorption over $700 \mathrm{~nm}$ are useful for applications in many areas such as photodynamic therapy (PDT), solar cells, semiconductors, catalysis and others. ${ }^{2,3}$

Due to these potential applications, methodologies for naphthalocyanine synthesis start from the traditional cyclotetramerization of building blocks such as naphthalonitriles and naphthalimides. This sometimes limits functionalizations, and results in poor yields due to the drastic conditions required. Therefore, the development of new methods which permit structural modifications, and also the enhancment of the photophysical and photochemical properties, are under study in our research group. ${ }^{4}$

Herein we propose to obtain naphthalocyanines by cross coupling reactions of halogenated phthalocyanines and vinylic esters, followed by onepot electrocyclic reactions.

\section{RESULTS AND DISCUSSION}

Our approach started with the synthesis of the building block 6 (Scheme 1). First, selective bromination of o-xylene (1) $\left(0^{\circ} \mathrm{C} \rightarrow\right.$ r.t., overnight, $54 \%$ yield) ${ }^{5 a}$ to compound 2 , was followed by oxidation to diacid $3\left(\mathrm{~K}_{2} \mathrm{MnO}_{4} / \mathrm{py}: \mathrm{H}_{2} \mathrm{O}\right.$, reflux, $\left.48 \mathrm{~h}\right)$ in $68 \%$ yield. $^{5 \mathrm{~b}}$ Compound 3 was heated at $235^{\circ} \mathrm{C}$ in the presence of urea (no-solvent) furnishing the corresponding phthalimide 4 in $80 \%$ yield. ${ }^{5 \mathrm{c}}$ Diamide 5 was obtained from 4 using a concentrated ammonium hydroxide solution at room temperature (59\% yield). ${ }^{5 d}$ Finally, phthalonitrile 6 was obtained in $63 \%$ yield by reacting 5 with $\mathrm{DMF} / \mathrm{SOCl}_{2}$ $\left(0^{\circ} \mathrm{C} \rightarrow\right.$ r.t.). ${ }^{5 \mathrm{e}}$

Heating phthalonitrile 6 in standard conditions in $\mathrm{N}, \mathrm{N}$-dimethylethanolamine (DMAE) and with zinc acetate, furnished octabromophthalocyanine 7 in $49 \%$ yield. ${ }^{5 f}$ We are now investigating cross-coupling reactions involving compound 7 and vinylic esters.

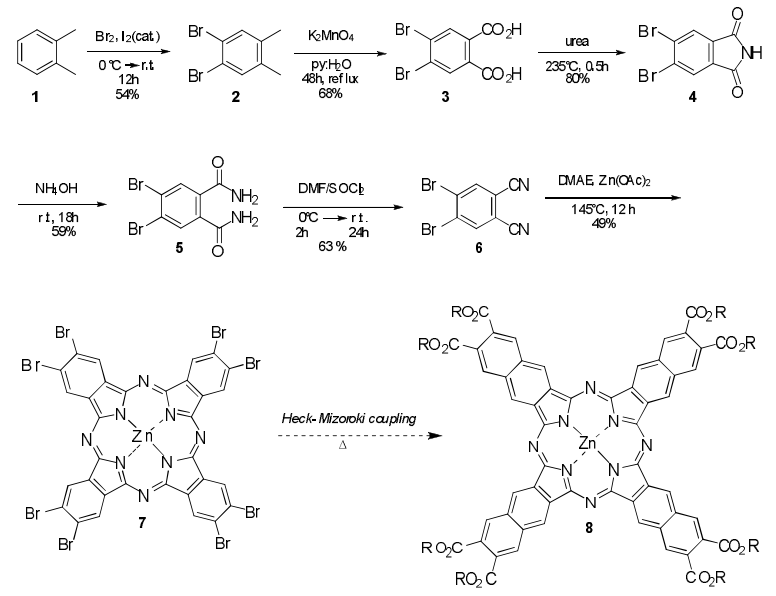

Scheme 1. Synthetic route for naphthalocyanines.

\section{CONCLUSION}

Octabromophthalocyanine 7 has been synthesized successfully. Cross-coupling reactions with one pot electrocyclic reactions are under study in order to synthesize naphthalocyanines by an original methodology.

\section{ACKNOWLEDGEMENTS}

The authors thank FAPESP (2013/06532-4, 2012/24092-9 and 2011/13993-2), CNPq and CAPES for financial support and fellowship.

\section{REFERENCES}

Muranaka, A.; Yonehara, M.; Uchiyama, M.; J. Am. Chem. Soc. 2010 132, 7844 .

${ }_{3}^{2}$ Rawling, T.; McDonagh, A. Coord. Chem. Rev. 2007, 251, 1128.

${ }^{3}$ Camerin, M.; Rello-Varona, S.; Vallanueva, A.; Rodgers, M. A. J.; Jori, G. Lasers in Surgery and Medicine 2009, 41, 665.

${ }^{4}$ Lukyanets, E. A.; Nemykin, V. N. J. Porphyrins Phthalocyanines 2010, 14, 5

a) Ashton, P. R.; Girreser, U.; Giuffrida,D.; Kohnke, F. H.; Mathias, J. P. Raymo,II, F.; Slawin,A. M. Z.; Stoddart, J. F.; Williams, D. J. J. Am. Chem Soc. 1993, 115, 5422. b) Dudič, M.; Císařová, Michl, J J. Org. Chem. 2012 77, 68. c) Crockett, G. C.; Swanson, B. J.; Anderson, D. R. Koch, T. H. Synthetic Communications 1981, 11, 447. d) Kuznetsova, N. A.; Shevchenko, E. N.; Makarov, D. A.; Slivka, L. K.; Solovyova, L. I.; Kaliya, O. L.; Lukyanets, E. A. J Porphyr. Phthalocy. 2012, 16, 1244. e) Wöhrle, D.; Eskes, M.; Shigehara, K.; Yamada, A. Synthesis, 1993, 194. f) de Oliveira, K.T.; de Assis, F. F; Ribeiro, A. O.; Neri, C. R.; Fernandes, A. U.; Baptista, M. S.; Serra, O. A.; lamamoto, Y. J. Org. Chem. 2009, 74, 7962. 